\title{
Anniversary of the commencement of the sg-3 Kola superdeep borehole drilling operations
}

\author{
El aniversario del inicio de la perforación del pozo superprofundo sg-3 de \\ Kola
}

\author{
Petr K. Skuf'in \\ Geological Institute of the Kola Scientific Centre, Russian Academy of Sciences, Apatity 184209, \\ Russian Federation \\ skuf@geoksc.apatity.ru
}

(recibido/received: 26-mayo-2021; aceptado/accepted:05-julio-2021)

\begin{abstract}
The presented article reviews the history of drilling the deepest well in the world, located in the northeastern part of the Early Proterozoic Pechenga structure (Kola Peninsula). In 1990, the Kola Superdeep Borehole (SG-3) reached a record depth of 12,262 m. SG-3 fully completed all the assigned tasks, both in technical and scientific terms. The 4024 linear meters of core were extracted, including drill samples from a record depth. Overall, a whole complex of logging geophysical works with a total length of 400 thousand $\mathrm{km}$ was performed through the use of 25 methods. This allowed obtaining the latest information on the structure and composition of the deep horizons of the earth's crust, which qualitatively changed the data of previous deep seismic studies. Also, the emerging data on the chemical and mineral composition, as well as the research of physical properties of deep rocks, proved the presence of ore mineralization and metal-bearing hydrothermal systems. SG-3 at its depth uncovered new ore bodies of copper-nickel ores; six types of ore mineralization have been identified throughout the section of the borehole. High permeability for fluids and hydrothermal solutions of deep zones of the earth's crust was established, which is associated with increased porosity and rocks fracturing. It was also proved that the earliest Precambrian metasedimentary rocks were formed with the active participation of biological processes. The presented analysis of the deep-hole drilling experience allows the author to confirm the status of SG-3 as the deepest artificial point on Earth.
\end{abstract}

Keywords: Superdeep drilling; Kola Superdeep Borehole (SG-3); Baltic shield; Archaean eon; Proterozoic Eon.

\section{RESUMEN}

El presente trabajo examina la historia de la perforación del pozo más profundo del mundo situado en la estructura del Proterozoico Temprano (Península de Kola) en el raión de Pechenga, en su parte noreste: el pozo superprofundo de Kola (SG-3), que en 1990 alcanzó una profundidad récord de $12262 \mathrm{~m}$. El SG-3 cumplió íntegramente con todas las tareas que le fueron asignadas, tanto técnica como científicamente. Fue posible la extracción de 4024 metros lineales del centro, incluso desde una profundidad récord. Además, se llevó a cabo todo un complejo de trabajos geofísicos de registro con una longitud total de $400 \mathrm{mil} \mathrm{km}$ con base en 25 métodos. Se obtuvo la información más reciente sobre la estructura y la composición de los horizontes profundos de la corteza terrestre, lo que cambió cualitativamente los datos de los estudios sísmicos profundos anteriores. Se obtuvieron nuevos datos sobre la composición química y mineral, así como sobre las propiedades físicas de las rocas profundas 
y se comprobó la presencia en ellas de mineralización de mena y sistemas hidrotermales portadores de metales. A la profundidad de SG-3 se descubrieron nuevos cuerpos de mena de los minerales de cobre y níquel. A lo largo de toda la sección del pozo se identificaron seis tipos de mineralización de mena. Se determinó una alta permeabilidad para los fluidos y las soluciones hidrotermales de zonas profundas de la corteza terrestre, lo que se asocia con el aumento de la porosidad y la fractura de las rocas. Está comprobado que las primeras rocas metasedimentarias del Precámbrico Temprano se formaron con la participación activa de los procesos biológicos. El análisis de la experiencia de la perforación profunda permitió afirmar que el SG-3 sigue siendo el pozo más profundo del mundo.

Palabras claves: Perforación superprofunda; Pozo de Kola SG-3; Escudo báltico; Eón arcaico; Proterozoico.

\section{INTRODUCTION}

It happened 50 years ago on 24 May 1970, at the centenary of the birth of Vladimir Lenin. That event could allow no Soviet geologist, petrographer, or mineralogists to stay indifferent. In the north-west of the Soviet Union, in the Murmansk region, a team of researchers began to drill the Kola Superdeep Borehole in the Early Precambrian crystalline rocks of the Baltic shield with a projected depth of 15 $\mathrm{km}$.

Comparing the satellite observations with studying the deep layers of the Earth's crust reveals their striking imbalance. Outer space has been studied by various methods as far as hundreds of kilometers away from the Earth, while the penetration into the depths of our planet is limited to only a few kilometers in wells drilled in pliant sedimentary rocks of hydrocarbon deposits. In their models, geologists have to either operate with implicit data on the composition and the properties of abyssal rocks, studying volcanic material, or rely on hypothetical, and often erroneous, deep profiles and sections suggested by geophysicists.

In the Soviet Union, the issue of studying the depth horizons of the Earth's crust using deep-hole drilling arose in the early 1960s. The prime objective was to make it possible to obtain new data that could help decipher the deep endogenous processes and the associated ore genesis (Kozlovsky, 1984).

In 1963, the Scientific Council was established to organize and manage the research on the problems of exploration of the Earth's interior and superdeep drilling. The council engaged the efforts of more than 200 geologists from various departments and institutions. The developed program of works, stretched throughout the 1970s, envisaged the creation of a scientifically grounded model of the Earth's crust and the upper mantle and the development of new mineral deposit prediction methods. It was planned, as the research activities progressed, to obtain the latest information about the material composition and physical characteristics of deep rocks. The program also aimed to discover the geological nature of seismic boundaries in the upper and depth horizons of the Earth's crust. The tasks set in the program required constant improvement of deep drilling equipment and technology and continuous development of new approaches to this demanding activity.

In addition to the borehole that later became known as SG-3, the council aspired to create a reference network of superdeep (deeper than 5-8 km) boreholes. The idea was to drill them in the most important ore-bearing regions of the country from the 1970s through the 1990s. The reference network would include the Ural borehole $(6.3 \mathrm{~km})$, the Saatlin borehole $(8.3 \mathrm{~km})$ in Azerbaijan, the En-Yakhin borehole $(8.25 \mathrm{~km})$ near Urengoy, the Timan-Pechora borehole $(7 \mathrm{~km})$, the Tyumen borehole $(7.9 \mathrm{~km})$, and the Shevchenko borehole $(7.5 \mathrm{~km})$ in Western Ukraine. The Kola and Saatlin boreholes were scheduled to be drilled first. On a related note, there are only seven superdeep boreholes in the world: four in the United States, one in Sweden, one in Germany, and one in Kazakhstan - and none of them has penetrated deeper than $9.5 \mathrm{~km}$. 
Deep boreholes are usually made to prospect deposits. In contrast, SG-3's mission was to obtain reliable scientific information on the structure and composition of the upper horizons of the continental crust, in particular, the transition zone between the Earth's crust and the upper mantle (the Mohorovichich discontinuity). Thus, SG-3 became the flagship in the reference network of superdeep boreholes in the Soviet Union.

The Academy of Sciences of the Soviet Union recommended that SG-3 should be drilled in the Pechenga ore region, where the largest $\mathrm{Cu}-\mathrm{Ni}$ ore deposits in Europe were formed. The borehole was located $10 \mathrm{~km}$ southwest of the town of Zapolyarny $\left(69^{\circ} 23^{\prime} 46^{\prime \prime} \mathrm{N}, 30^{\circ} 36^{\prime} 31^{\prime \prime} \mathrm{E}\right)$. Sited in the northern flank of the Early Proterozoic Pechenga structure, SG-3 uncovered sections of Proterozoic rocks with an age of 2300-1900 Ma and located deeper than Archean rocks of a granite-gneiss basement with an age of 3100-2800 Ma (Kozlovsky, 1984). Eighteen research institutes and more than fifty large industrial enterprises took part in the preparation and organization of drilling. All the mechanisms and materials were of domestic origin. Three thousand participants joined the Kola geological exploration expedition. A powerful modern enterprise emerged in the deserted tundra, with a large complex of buildings and facilities, including residential premises, a dining room seating 220 , and a medical center (Fig. 1).

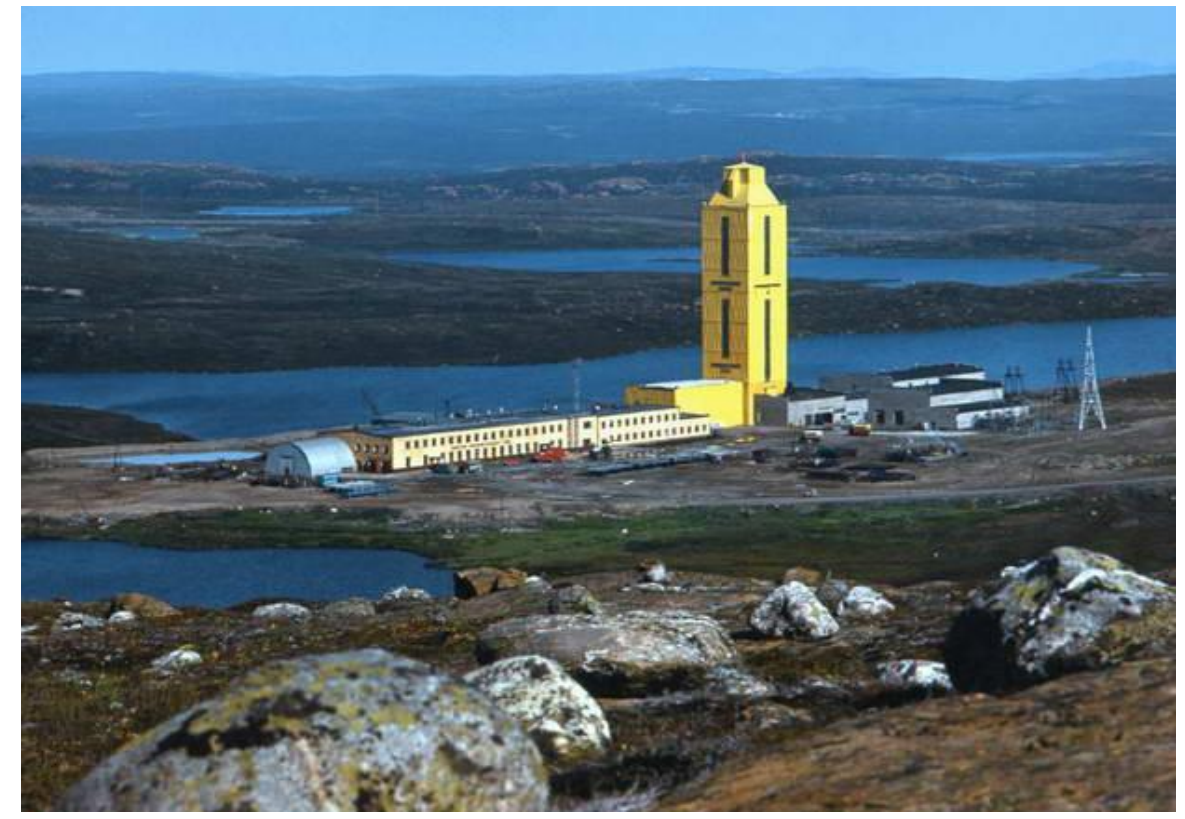

Figure 1. Kola Superdeep Borehole (SG-3)

The Kola Superdeep Borehole was a classified object, and Soviet newspaper Pravda casually informed the public about it only in 1975 in a short article by the Minister of Geology Alexander Sidorenko. No academic publication appeared until the collapse of the Soviet Union, although sixteen research laboratories of various scientific institutions diligently worked at the borehole site. The author himself was also among the members of the large team of geologists-specialists who conducted longterm studies of the Early Precambrian rocks from the SG-3 core.

With this article, the author expresses hope to draw the attention of the scientific community to deephole drilling. Such projects should be commenced on a global scale with a view of solving the cardinal task of geology, i.e. to create an objective model of the Earth's crust and the upper mantle and to reveal the material composition and the physical characteristics of deep rocks. It can be an incentive to design the advanced deep drilling equipment and to develop optimal approaches to the organization of such works. Deep exploration of the Earth is the only way to understanding the chemical makeup and the natural processes in the abyssal depths of the planet, safeguarding resources for future industry, and guaranteeing the economic and social development of humanity. The article addresses the history of the Kola Superdeep Borehole in three aspects: (a) the scientific and technical outcomes of the SG-3 
project; (b) the possibilities and conditions for the resumption of drilling operations at the preserved SG-3 site; d) the possibilities and prospects of deep exploration of our planet using deep drilling.

\section{MATERIALS AND METHODS}

The presented publication leans on the fundamental principles of the methodology of cognition. First, the principle of the unity of theory and practice made it possible to evaluate the results obtained by researchers at the Kola Superdeep Borehole from the standpoint of the increment of theoretical knowledge and practical experience. Second, the principle of objectivity made it possible to take into account the objective factors in the process of deployment, implementation, and wrap-up of the SG-3 project. Third, the principle of specificity made it possible to identify specific approaches to assessing the results of project implementation. Fourth, the principle of development made it possible to show the evolution of knowledge on the depth horizons of the Earth's crust as this knowledge changed in the process of handling the research data. Fifth, the principle of consistency made it possible to assess the connection between the results obtained under the project and the general problems of studying the Earth's crust and the mantle. Sixth, the principle of historical and logical unity declares that the history of science serves as a key to understanding the logic of the formation of scientific ideas about a specific process as about a certain stage in the development of scientific knowledge as a whole.

The article largely refers to the colossal bulk of data that had been accumulated over many years by the team of geologists, starting with primary records and sketches in the site logs and continuing with layer-by-layer records of the extracted core pieces directly in the core storage at the drilling rig. The rich collection of samples of igneous and metamorphic rocks from the borehole core had been investigated in detail using a wide variety of methods. Thousands of thin sections and polished sections from SG-3 had been thoroughly studied and described. The result of the research activities was a detailed picture of the geological and geochemical features of the borehole rocks, their chemical and mineral composition, and ore content (Kozlovsky et al., 1988; Lobanov et al., 2013, 2020). The absolute age of hundreds of rock samples was measured (Bayanova et al., 2000), and the chemical properties and the structure of minerals were described (Skuf'in \& Lyutoev, 2009).

Also, the article draws from materials of the author's personal archive, colleagues' archives, and the SG-3 archive that had accumulated hundreds of accounting, descriptive, metrical, etc. documents over a long period of work. All the materials produced by the project were filed, and now they are available for review and study. All the materials, including extracts from the records, are of the public domain.

Other sources of information include the author's academic papers, information from companies engaged in deep drilling, scientific publications in journals, materials of scientific and practical conferences and seminars, and Internet resources.

\section{RESULTS OF THE IMPLEMENTATION OF THE SG-3 PROJECT}

\subsection{Cutting-edge drilling equipment and hole-making technique}

Before 1975, drilling was performed by a serial Uralmash-4E drilling rig, usually used to drill oil and gas wells. From 1975 to 1991, the drilling team operated a specially designed Uralmash-15000 drilling rig that weighed 15,000 tons and had a 74-meter high tower (Fig. 2). The unique technology, developed to drill SG-3, allowed for the first time in world practice to reach a depth of $12,262 \mathrm{~m}$ in crystalline monolithic rocks. It was in the 1997 Guinness Book of Records. 


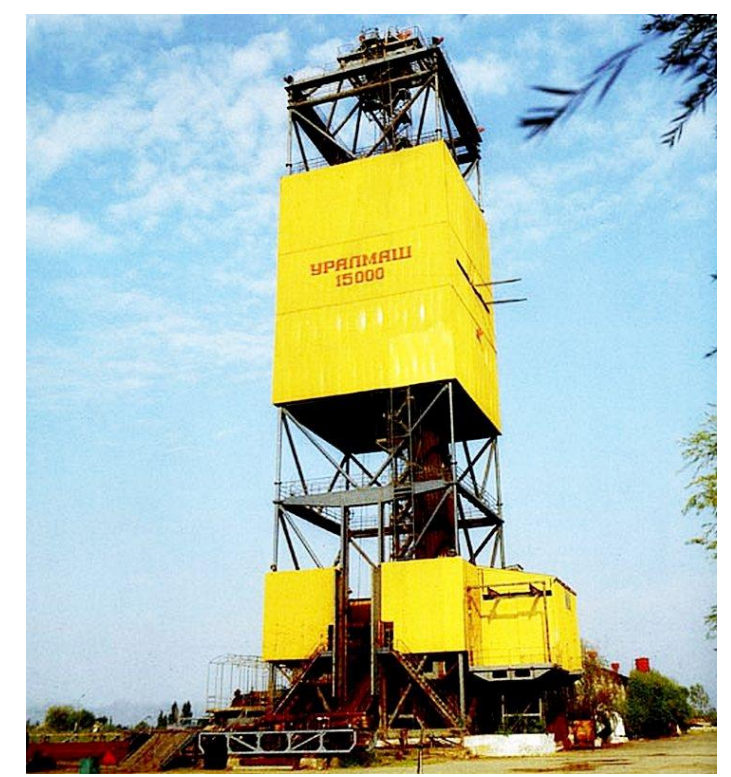

Figure 2. Uralmash-15000 drilling rig

The SG-3 rig was a high-tech facility with a powerful foundation on which a sectional 74-meter tower was erected. The facility was equipped with state-of-the-art means for drilling, lowering, and lifting a drill string, holding the entire pipe string during tripping and drilling (Kozlovsky, 1984). Numerous technical and electronic developments ensured the safety of drilling. The inner space of the tower housed power and technological equipment, power generating and pumping units, automated drilling control, and lab equipment complex. When drilling the SG-3, the latest measuring instruments were used to control a wide variety of processes, from the surface to the very bottom of the borehole. Regular logging with instruments run into the borehole on heat-resistant wireline proved to be ineffective. Employed modern compact telemetry and electronic sensors were finally able to could move from depth in a stream of mud, delivering to the surface the measurements of various physical properties of deep rocks.

The conduct of operations employed the advanced experience of deep-hole drilling, including the development of the drill string design. The latter, at the moment of separation of the drill from the bottom, weighed more than 200 tons at a depth of $12 \mathrm{~km}$. Assembled from drill pipes of special ultrastrong aluminum alloys and being placed in a weighted borehole mud, the string, nevertheless, could not withstand enormous loads and began to stretch like rubber. As a result, the length of the drill string during lifting had increased by almost 50 meters (Yakovlev et al., 2014). The drilling operations employed a turbo-drill - a hydroturbine motor with a length of 46 meters, rotating under the fluid pressure, which drove the special carbide drill bits. One bit served approximately 4 hours, allowing an advance rate of 7-10 meters. The drilled rock samples (core) entered the core receiver - a removable pipe inside the turbo-drill. To replace the drill bit and extract the core, the drill string was lifted and then lowered. This part took 18 hours or more. When lifting, the column was disassembled into sections of several pipes, which were installed in the form of an assembly inside the tower.

The friction of the drill string against the borehole walls (particularly while passing the curvature) resulted in additional loads on the SG-3 lifting mechanisms. The loads could reach up to $65 \%$ of the string weight, which often led to jamming and breakage of the drill string. Then the lost part of the string was cemented, and the vertical drilling continued with the drilling tool deflected at the break. Such accidents happened on multiple occasions, so drilling continued for many years. The most difficult drilling conditions and high temperatures at the SG-3 bottomhole, reaching up to $220^{\circ} \mathrm{C}$ at a depth of $12 \mathrm{~km}$, led to repeated accidents, breaks, and loss of drilling equipment. As a result, five parallel boreholes in SG-3 were driven below the base depth of $7 \mathrm{~km}$. 
In 1983, one of them reached a depth of $12,066 \mathrm{~m}$, but the drilling was temporarily suspended as the state was preparing for the International Geological Congress, which was to be held in 1984 in Moscow. Continued on September 27, 1984, the drilling experienced an accident on the very first run: the drill string broke off again. The operations resumed from a base depth of 7,000 m, and by 1990 the SG-3 parallel borehole had reached a record depth of 12,262 meters. The SG-3 team was preparing to reach a depth of $14 \mathrm{~km}$, but the drill string broke off again, and then the drilling was stopped by government decision. In 1991, the project received the status of the Federal Research Center (Kola Science Center). In 1995-2007, the Center was operating as the site for the Russian Deep Geo Lab. At this time, it was actively used as the basis for studies conducted by more than 20 countries under UNESCO and the International Geological Union international projects. In subsequent years, the site of Kola Lab was operationally closed due to financial difficulties and a lack of state support. Still, the projects for further development could bring the country huge profits at relatively low costs: by the closing time, the annual budget of the Center was 3 million rubles. In 2008, SG-3 was mothballed; the equipment was partially dismantled, and partially plundered for scrap, the tower itself and production facilities turned into ruins (Fig. 3.4).

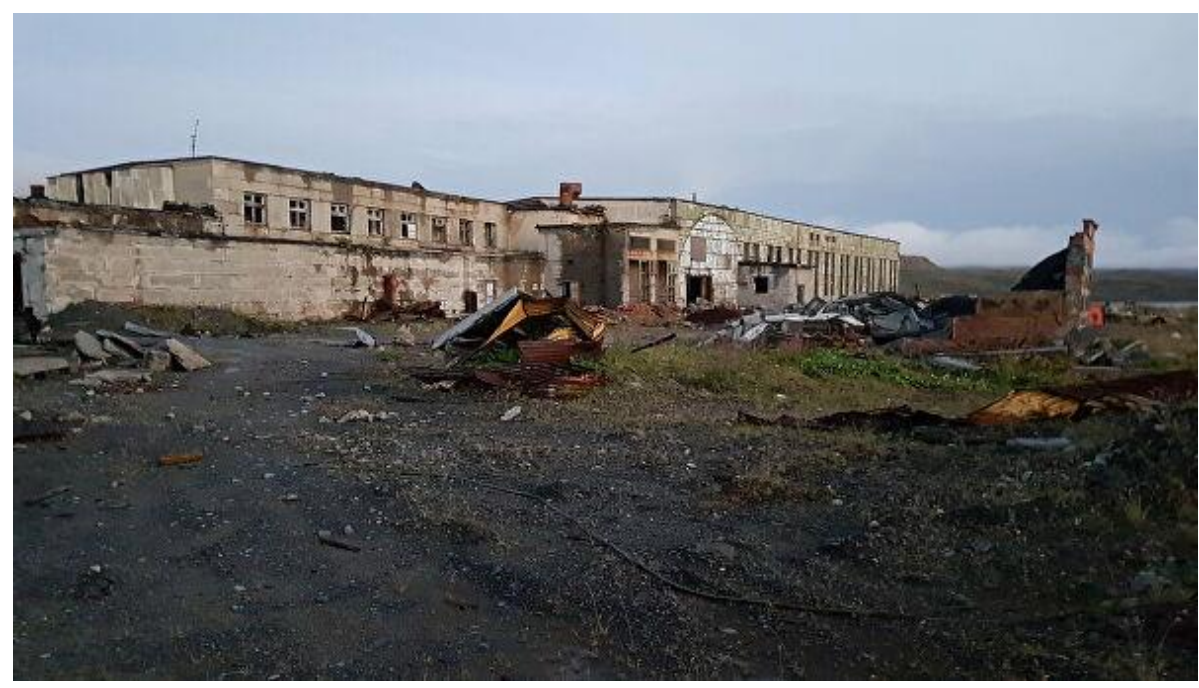

Figure 3. Ruins of the Kola Superdeep Borehole site facilities

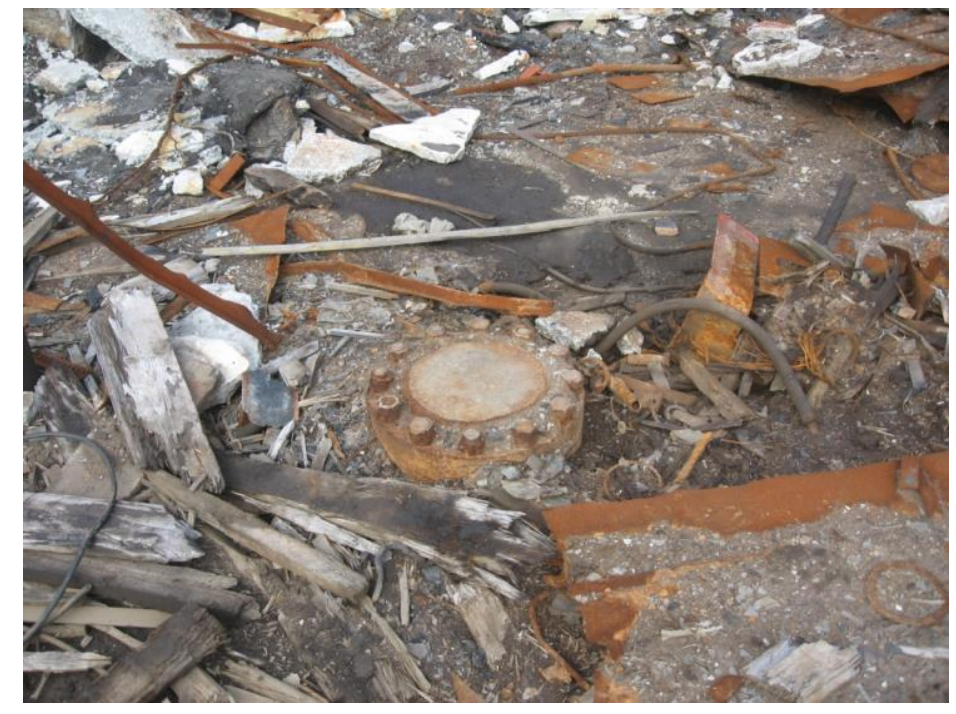

Figure 4. Mothballed opening of the SG-3 borehole

\subsection{Technical and scientific results of the performed operations}


SG-3 fully completed all the assigned tasks, both in technical and scientific terms. The 4024 linear meters of core were extracted, including drill samples from a fantastic twelve-kilometer depth. A whole complex of logging geophysical works with a total length of 400 thousand $\mathrm{km}$ was performed through the use of 25 methods (Guberman et al., 2006). The research revealed a large amount of unique information on the earth's interior; the results were largely unexpected and, to a large extent, not yet appreciated by the scientific community and humanity as a whole. First to mention was the high permeability for fluids of the deep zones of the earth's crust established in the process of drilling. Thus, it was generally believed that the solidity of rocks increases with depth while their porosity, fracturing, and general permeability decrease. However, in fact, the density of cracks and porosity of rocks remained unchanged at great depths. Contrary to forecasts, it even increased in some areas. The superheated water and fluid flow circulated under high pressure at depth in these fractured zones. There were serious projects in the 60-the70s of the last century on the disposal of liquid radioactive waste and toxic substances by pumping them into the deep layers of the earth's crust. Humanity owes great respect to the SG-3 team for warning about the dangers of such wacky ideas because hydrothermal flows would definitely spread radioactivity throughout the thousand-kilometer surrounding space and poison the deep waters of the world's largest countries for hundreds of years.

For the first time, unique data were obtained on the structure, composition, and temperature characteristics of the deep zones of the earth's crust, physical properties, and geochemical features of deep rocks; the presence of ore mineralization and metal-bearing hydrothermal systems was also proved (Kozlovsky et al., 1988; Orlov \&Laverov, 1998). At a depth of 1600-1800 m, researchers discovered ore deposits with industrial types of $\mathrm{Cu}-\mathrm{Ni}$ ores. The depth of 9500-11100 m revealed a zone with a sufficiently high content of $\mathrm{Au}$ and $\mathrm{Ag}$ in granite-gneisses. Also, the deep-seated magmatic gneiss-granites uncovered the presence of hydrocarbon gases, including methane in significant concentrations. This is another argument in favor of the inorganic origin of hydrocarbons.

In no small part, unexpected results were obtained when measuring real temperatures at great depths. Earlier it was assumed that within the granite-gneiss basement of the Baltic Shield, the temperature increases insignificantly with depth (by about $8-10^{\circ} \mathrm{C}$ per $1 \mathrm{~km}$ ). However, instead of the expected $120^{\circ} \mathrm{C}$, the actual temperature in the borehole reached $180^{\circ} \mathrm{C}$ at a depth of about $10 \mathrm{~km}$, and $212^{\circ} \mathrm{C}$ at a depth of $12 \mathrm{~km}$. Perhaps this phenomenon is explained by increased tectonic activity in the deep zones of the earth's crust.

It was established as a result of a comprehensive study of the Kola superdeep rock core that deep metasedimentary gneisses and granite-gneisses were formed with the active participation of biological processes. Isotope analysis of carbon revealed two sources of its origin: the first is of mantle origin, and the second is biogenic. Noteworthy that biogenic carbon significantly predominates in Proterozoic metasedimentary rocks. The latter also contains the remains of microorganisms aged more than 2 billion years. Thus, Vladimir Vernadsky's idea on the presence of Early Precambrian biospheres on Earth was proved to have a basis in fact.

Moreover, the borehole gamma logging resulted in establishing the vertical zoning of the distribution of the concentrations of uranium, thorium, and potassium. This scientific discovery, confirmed by other geophysical methods, is an important contribution to the development of a general thermal model for the formation of the Earth's crust in the Early Precambrian.

A performed complex of versatile geophysical studies allowed SG-3 specialists, relying on a network of drilled superdeep (over $7 \mathrm{~km}$ ) boreholes in other regions of the USSR, to track changes in geophysical parameters in three-dimensional space and in a single time. The further developments also provided for building three-dimensional spatial models of the stress states of the earth's crust and predict their changes, which made it possible to forecast earthquakes and catastrophic shifts of tectonic plates for many thousands of km from SG-3 (Lobanov et al., 2020). The industrially developed states of the world, located in seismically hazardous zones (and Japan above all), allocate tens of billions of dollars for research related to the study and forecasting of earthquakes, volcanic eruptions, catastrophic movements of lithospheric plates, and other natural disasters associated with the release 
of tensions in the depths of our planet. Continuation of research work at SG-3, shortsightedly stopped at the end of the last century, would in many ways bring humanity closer to solving the problems of safety for the people living in tectonically tense regions of the world. At the same time, dozens of problems related to tracking the patterns of changes in geophysical parameters in the layers of the hydrosphere and lithosphere could also be solved. This includes, for instance, the possibility of detecting submarines and other underwater objects in the oceans of the Earth as well.

The SG-3 research team also made a number of important discoveries concerning the structure of the lithosphere as a whole. The drilling results refuted the existing ideas about the structure of the earth's crust around the entire Baltic shield and in the borehole area in particular. The projected geological sections drawn up by geophysicists have not been confirmed in any of the cases. An experienced geophysicist and an employee of the Geological Institute of the Kola Scientific Center, N.V. Sharov worked on the Baltic Shield for decades. Sharov undervalued the previous results of seismo-geological studies on the crystalline shields of the world (Sharov, 2012): 'Deep drilling has provided direct data on the composition and structure of the earth's crust down to a depth of $12 \mathrm{~km}$, which showed that we know nothing about the continental crust. Deep wells have shown that the heterogeneities recorded by geophysical data in the upper part of the crystalline crust are due to changes not only in the composition of deep rocks but also in their physical state. Therefore, the determination of even an approximate composition of rocks from the values of only the velocity of propagation of elastic waves is still a debatable issue.'

The results obtained in the process of drilling forced geologists to abandon the simplified concept of the three-layer structure of the earth's crust, where the first comes a layer of sedimentary rocks, then granite, and below - basalt, the rocks of which are already underlain by mantle peridotites. Based on seismic data, the projected SG-3 section predicted the shift of the volcanic-sedimentary rocks of the Pechenga structure at a depth of $4 \mathrm{~km}$ to the gneiss-granites of the Archean basement. Having drilled out a three-kilometer layer of granite-gneisses and a relatively thin basalt layer in this structure, the well should have plunged into the mantle rocks. The core of the mantle formations, which none of the earthlings had ever held in their hands, was to be touched for the first time - almost lunar sample in the hands of an astronaut! However, all these hopes were denied by reality: the rocks of the Pechenga structure extended to a depth of $6842 \mathrm{~m}$, and only then were replaced by Archean granite-gneisses. And the basalt layer was not found at all - until the record depth, the drill made its way through the Archean granitoid rocks. Geologists expected a soon discovery of the pronounced boundary between the granite and basalt, but only granitoids were found in the core throughout the entire depth. The fact is that compacted granites significantly changed their density characteristics during compaction due to high pressure. The minerals of these rocks were also replaced by denser mineral modifications, and during seismological studies using the methods of longitudinal and transverse elastic waves, these compacted granitoids were perceived by geophysicists as denser than standard granites, basalts, or even denser mantle rocks. These misconceptions about the deep structure of the Kola Peninsula were actually the basis for the projected section of the borehole. Later it turned out that the boundaries between the 'granite' and 'basalt' layers are quite arbitrary and the rocks of basic and felsic composition are often interbedded at depth as a result of deep thrusting. Also, the very Mohorovičić discontinuity between the crust and the mantle in the earth cannot be clearly marked since it turned out to be often arbitrary as well (Orlov \&Laverov, 1998).

Teaming up with geologists-specialists of SG-3 (chief geologist Yu.N. Yakovlev, geologist Yu.P. Smirnov) and Geological Institute of the Kola Scientific Center (T.B. Bayanova, V.R. Vetrin, F.F. Gorbatsevich), the author was directly involved in the study of the geology of the Early Precambrian rocks of the well for quite some years (1999-2016). Although the studies concerned the gneissicgranites of the Archean basement (Skuf'in \& Vetrin, 2002), they still were mostly focused on the supracrustal rocks of the Pechenga complex, the complete section of which was exposed by SG-3 in the interval 0-6842.0 m (Skuf'in et al., 1999; Skuf'in, 2013; Gorbatsevich et al., 2016). In addition, auxiliary structural wells IX (depth $1300 \mathrm{~m}$ ) and X (depth $1100 \mathrm{~m}$ ) were investigated in detail, which made it possible to trace the rocks from the SG-3 section throughout the uprising (Skuf'in, 2013). 
The Kola Superdeep Borehole was drilled in the N-E part of the Early Proterozoic Pechenga structure, composed of volcanic-sedimentary rocks of the Pechenga complex (aged 2550-1940 Ma), the section of which is formed by 4 volcanogenic Suites (VS), at the base of which are thin sedimentary Suites (SS). From bottom to top, as follows: I VS, II VS, III VS and IV VS (Fig. 5).

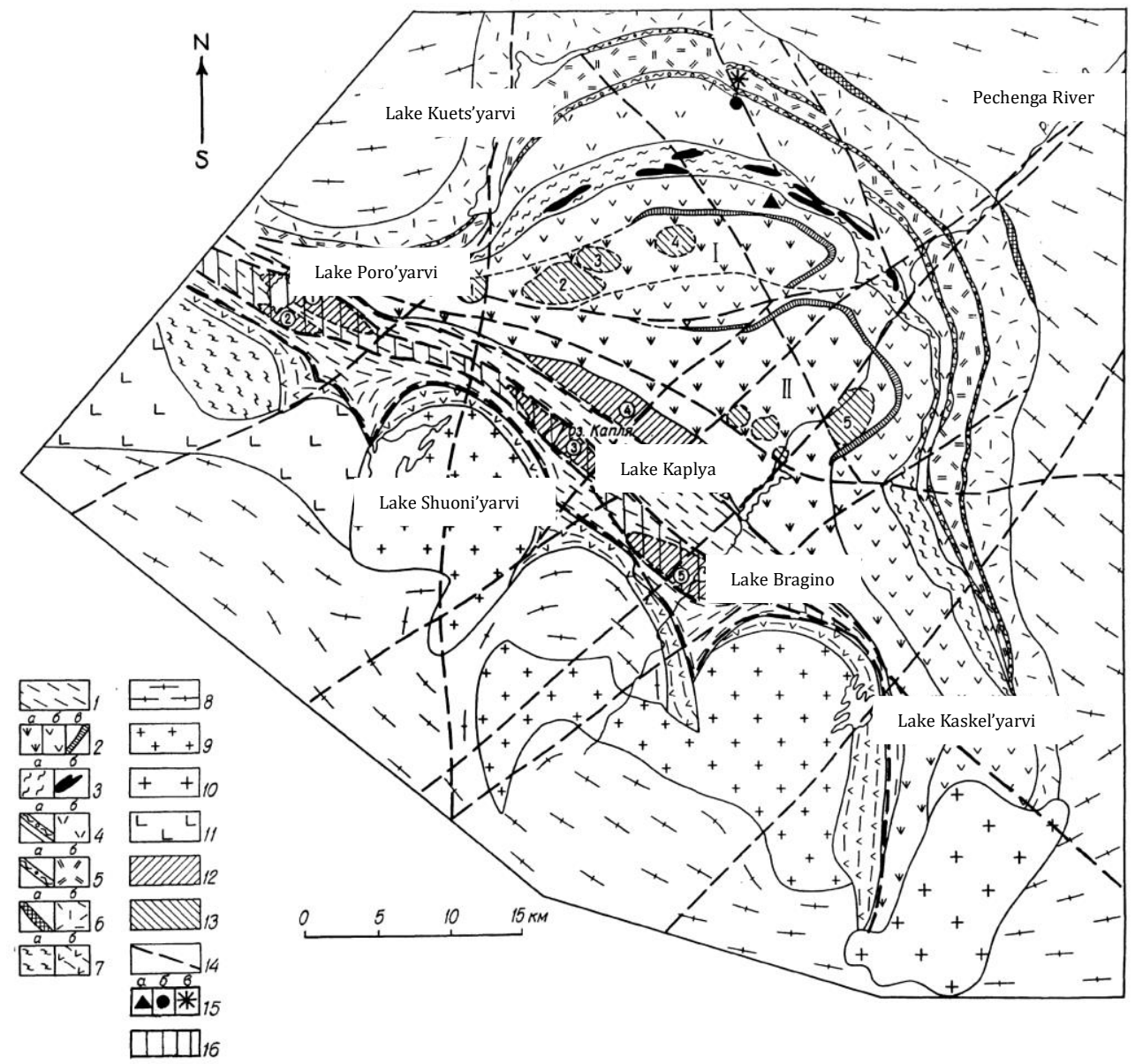

Figure 5. Geological features of the Pechenga structure: 1 -the South Pechenga complex; $2-6-$ Pechenga complex (VS - Volcanic Suite; SS - Sedimentary Suite): 2 - IV VS: (a) upper subsuite of basite rocks, (b) lower subsuite of basite rocks, (c) horizon of felsic rocks; 3 - IV SS: (a) metasediments, (b) ore-bearing intrusions; 4 rocks III SS (a) and III VS(b); 5 - rocks II SS (a) and II VS (b); 6 - rocks I SS (a) and I VS (b); 7 - (a) gneiss-

schists, (b) amphibolites; 8 - gneiss-granites of the Archean basement; 9 - plagiogranites (1940 Ma); 10 microcline granites (1762 Ma); 11 - gabbro; 12 - volcanic centers in the South Pechenga zone; 13 - volcanic centers in the North Pechenga zone; 14 - faults; 15 - the SG-3 borehole (a) and structural borehole IX (b) and X (c); 16 - Poroyarva near-fault trough (Skuf'in, 2013).

Surface and subsurface samples of volcanic rocks of the Pechenga complex can be considered homologous, taking into account the change in their lateral composition and the conditions of metamorphism with depth. The research process was necessary to establish the degree of conformity of volcanic rocks samples from the SG-3 section and from near-surface wells IX and X to their surface homologs by composition and petrophysical characteristics, including their similarities and the features of differences caused by the impact of high pressures and temperatures on subsurface samples.

The sections of both surface and deep-seated rocks of the youngest III VS and IV VS are represented by a uniform sequence of weakly metamorphosed globular lavas of tholeiitic composition. Volcanic rocks of this level are identical in chemistry and petrophysical properties. Therefore, the research was focused on the study of the section of deeply buried rocks of more ancient I and II VS, composed of metamorphosed interbedded volcanites of various structures. A comparison of their properties was 
conducted to determine the distinctive features of the surface, near-surface, and deep regimes of the Early Precambrian mineragenesis.

As a result of petrogeochemical studies, it was established that rocks I VS and II VS in different structural-tectonic zones have different facies and certain differences in chemical composition. The composition of deep volcanic rocks I VS is similar to the composition of surface and near-surface homologs, which indicates the isochemistry of metamorphism, from surface prehnite-pumpellyite to deep amphibolite facies of metamorphism. Deep-seated samples are only slightly depleted in iron oxide. At the same time, the study of volcanites II VS indicates a significant difference in the composition of deep and near-surface rocks and their surface homologs. Compared to surface samples, the deep homologs manifested averaging and homogenization of the composition. In comparison with the surface homologs, the subsurface samples of the lower horizons of II VS are enriched in $\mathrm{Al}_{2} \mathrm{O}_{3}$, partly in alkalis, but depleted in iron oxide and silicic acid. At the same time, the proportion of subalkaline rocks (mainly alkali-basalts) in the volcanites of the upper horizons of II VS sharply increases (from 20 to 70\%) due to the significant enrichment in alkalis of the initial ferrobasalts, whose proportion in the surface homologs makes up more than 50\%. In fact, several factors make it possible to associate the increased alkalinity of rocks of this level with dislocation metamorphism in the circle of influence of the large-scale Luchlompolsky fault zone.

\section{DISCUSSION}

\subsection{Terms and conditions for the resumption of well operations on the preserved SG-3 wellbore}

According to the director of the Geological Institute of the Kola Science Center, prof. Voitekhovsky, the current condition of the Kola Superdeep Borehole is precarious: the well has been mothballed and the structure over the borehole has been partially destroyed or removed. The restoration cost is estimated at one hundred million rubles. Professor Voitekhovsky is entitled to his opinion that there is still an opportunity at the moment to restore the scientific significance of SG-3 and, in particular, to open a research and production center for training specialists in deep-hole drilling. The borehole has a working shaft with a diameter of $20 \mathrm{~cm}$ to a depth of $4 \mathrm{~km}$, welded with an armor plate to protect from vandals (Fig. 4), and then the shaft with a diameter of $10 \mathrm{~cm}$ continues to a depth of $8 \mathrm{~km}$. The access equipment has not survived, but the logging hardware can make it down with a conventional logging hoist. This may allow in no time to initiate a wide range of possible operations: studying the deep layers of the lithosphere, building three-dimensional geophysical models of large blocks of the earth's crust, predict earthquakes or catastrophic shifts of tectonic plates, and solve dozens of other important scientific problems. Dozens of research centers in Russia and abroad are showing interest in this unique object. Perhaps the Kola Superdeep Borehole has not yet said its last word.

SG-3 is still the deepest artificial point on Earth, although it was bypassed in length by the Maersk Oil BD-04A oil well drilled in 2008 at an acute angle to the surface with the length of 12,290 meters (located in Al Shaheen Oil Field in Qatar), as well as an by an oil well of the Odoptu-Sea field of the Sakhalin-1 project with a length of $12,345 \mathrm{~m}$, drilled in 2011 , and also at an acute angle to the earth's surface. Well, drilling at an acute angle and in fragile sedimentary rocks could be extended up to 15 $\mathrm{km}$. Yet, the vertical drilling to such a depth in monolithic crystalline rocks in modern conditions is comparable in cost to the implementation of a large-scaled space program. The Soviet project cost around 400 million rubles. Given the fact that the state, implementing this prestigious project, practically did not consider the costs, vertical drilling in monolithic rocks to a depth of 14-15 km will currently require colossal efforts and costs of several billion dollars.

\subsection{Opportunities and prospects for exploring the planetary interior using deep-hole drilling}

It can be stated with confidence that the closure of the Kola Superdeep Borehole was a blankly reckless and ill-considered decision. Noteworthy that if during the SG-3 drilling and the processing of the obtained materials caused dozens of publications on these issues, then in recent years, scattered publications more often concern purely technical problems, such as neutron tomography of individual 
samples of the SG-3 section (Kichanov et al., 2015), or use of simulation analysis to compensate for wellbore deviations during deep-hole drilling (Gerken et al., 2020). Some of these publications also consider the problems of reinterpreting previously published materials in the light of new hypotheses and concepts (Gorbatsevich et al., 2016, 2020; Yakovlev et al., 2017).

Meanwhile, the fact of a sharp reduction in explored and a probable reserve of minerals (in particular, hydrocarbons and metal ores) is recognized as alarming by all of the developed countries. This reduction forced a number of major states (and China above all) to re-evaluate the possibility and necessity of the earliest possible development of superdeep drilling projects. In 2016, the China Geological Survey launched the Deep Geological Survey Project to continuously explore the planetary interior. The main attention is paid to the national strategy in the field of deep exploration of energy resources. The drilling experts from China Geological Survey (Lü et al., 2020) believe that 'Deep-hole drilling is a way to understand the material composition, structure and dynamic process of the inner spheres of the Earth.' The question was posed even more specifically by Chinese geological engineers (Zhao et al., 2017): 'Deep-hole drilling is becoming the direct and most effective means of exploiting mineral resources. To determine the limit of crustal drilling depth, we conducted tests for the case of well deformation under high P-T conditions using a triaxial server system for the very first time.'

Drilling specialists from the China Geological Survey have so far focused on deep-hole drilling in Chinese oil basins. However, deposits of metal ores around the world are associated mainly with shields - aerial locations of the platform on which the Early Precambrian crystalline basement comes to the surface of the planet. The richest deposits of metallic ores and precious metals on large crystalline shields have been explored in intrusive rocks and deeply metamorphosed metasedimentary formations. China does not have such large shield structures as the Canadian or Baltic shields. However, significant outcrops of the ancient basement are known on the Liaodong and Shandong peninsulas, as well as on the Jiangnan shield of the South China platform. If China, with its inexhaustible resources, begins deep exploration drilling in these territories, the record highs of SG-3 will soon be shattered.

Certain shifts in that process are already taking place, and Russia is surprisingly the champion of the project to resume superdeep drilling. Roman Panov, the General Director of Russian multi-industry geological holding Rosgeologia, in his interview on 6.04.2018 to the Argumenty Nedeli weekly (htpp: //www.mstu,edu.ru) announced a project development for drilling four superdeep wells up to $7 \mathrm{~km}$ deep. The first of them will be commenced in North Caucasus to test the hypothesis on the presence of large abyssal hydrocarbon deposits.

The very symbol of the Kola Superdeep Borehole gradually penetrates deeply into human consciousness. During a briefing on May 20,2020, Deputy Governor of the Murmansk Region Olga Kuznetsova announced the regional government's decision to restore SG-3 and transfer it to federal ownership in the status of a tourist attraction (https://tass.ru/obschestvo/8520227). Nowadays, numerous full-length motion pictures and documentaries about the Kola Superdeep are filmed in the Russian North; however, they often appear with a mystical tinge, insinuating in every possible way about the underworld allegedly awakened as a result of drilling.

\section{CONCLUSION}

The superdeep drilling project 'Kola Borehole SG-3' has been completed and resulted in achievements of global significance. The main task that the creators of the project had in mind was the development of knowledge on the structure of the planetary interior. Thus, due to their efforts, humanity has made great progress in solving this task. Moreover, strong preconditions have been created for the development of the fundamental foundations of the theory of the Earth's crust formation in the Early Precambrian. The research revealed quite meaningful data on the structure of the planetary interior. The results turned out to be largely unexpected; they are also not yet sufficiently systematized. Due to objective reasons, several issues require further study. In particular, this refers to the development of knowledge on the essence of the most important interface between the mantle and the lower horizons 
of the earth's crust - the Mohorovičić discontinuity, and crisper understanding of nature and features of the mantle itself. An attempt to successfully solve this task directly depends on the continuation of large-scale deep-hole drilling operations.

It is a common belief that a new period of study of the continental crust of our planet began with the successful drilling of the Kola Superdeep Borehole. Superdeep drilling on the continents and in the oceans will eventually develop into a new branch of science and technology, which will combine the latest achievements of scientific and technological progress in general and geological sciences in particular. The opportunity of studying the planetary interior will open up new and not yet known patterns of the Earth's development for geologists. This, in turn, will make it possible, on a real basis, to investigate the features of geological processes at great depths, including the processes of ore formation. Rigorous research of the earth's interior is not only about common striving to acquire knowledge for mankind. It is also about meeting the basic needs of mankind in obtaining resources and guarantees of economic and social development.

\section{REFERENCES}

Bayanova, T., Mitrofanov, F., Skuf'in, P., Vetrin, V., Yakovlev, Yu., Smirnov, Yu., \& Yakovleva, A. (2000). U-Pb geochronology of Kola Superdeep borehole rocks and their homologs on the surface. In Abstracts of International Conference Svecolapca (pp. 11-12). Svecolapca Press

Gerken, J. F., Klages, N., Biermann, D., \& Denkena, B. (2020). In-process compensation of straightness deviation in BTA deep hole drilling using experimental and simulative analysis. Procedia CIRP, 93, 1417-1422.

Gorbatsevich, F. F., Vetrin, V. R., \& Kovalevsky, M. V. (2020). Crystalline crust according to the drilling of the Kola Superdeep Borehole. Priroda, 8(1260), 13-21.

Gorbatsevich, F. F., Skuf' in, P. K., \& Kovalevsky, M. V. (2016). Geological and geochemical features of the Pechenga complex at deep horizons of the section of the Kola Superdeep Borehole SG-3. In Regional Geology, Mineralogy and Minerals of the Kola Peninsula. Proceedings of the 13th Fersmanov Scientific Session, Apatity, Russia, 4-5 April 2016 (pp. 129-132). Apatity: Russian Academy of Sciences - Kola Science Center.

Guberman, D. M., Yakovlev, Y. N., Yakovleva, A. K., Pisarnitskaya, T. F., Mitrofanov, F. P., Bayanova, T. B., Vetrin, V. R., Ikorsky, S. V., Skuf'in, P. K., Sholpo, V. N., \& Morozov, Y. A. (2006). Complex of geological research during geo-monitoring in the SG-3 shaft and its geospace. Rossiyskiy geofizicheskiy zhurnal, 41-42, 56-63.

Kichanov, S. E., Kozlenko, D. P., Ivankina, T. I., Rutkauskas, A. V., Lukin, E. V., \& Savenko, B. N. (2015). The neutron tomography studies of the rocks from the Kola Superdeep Borehole. Physics Procedia, 69, 537-541.

Kozlovsky, Y. A. (1984). Kola Superdeep: Investigation of the Deep Structure of the Continental Crust by Drilling a Superdeep Borehole. Moscow: Nedra.

Kozlovsky, Y. A., Guberman, D. M., \& Kazansky, V. I. (1988). Ore content of deep zones of the ancient continental crust (based on findings from the Kola superdeep borehole). Sovetskaya geologiya, 9, 3-11.

Lobanov, K. V., Gornostayeva, T. A., Prokofiev, V. Y., \& Chicherov, M. V. (2020). SG-3 space flight into the depths of the planet Earth. In Regional Geology, Mineralogy and Minerals of the Kola Peninsula. Proceedings of the $17^{\text {th }}$ Fersmanov Scientific Session, Apatity, Russia, 5-8 April 2020 (pp. 322-327). Apatity: Russian Academy of Sciences - Kola Science Center. 
Lobanov, K. V., Kazansky, V. I., \& Chicherov, M. V. (2013). Gold mineralization in the Kola Superdeep Borehole sequence and at the surface in the Pechenga Ore Province. In Gold of the Fennoscandian Shield. Proceedings of the International Conference, Petrozavodsk, Russia (pp. 121125). Petrozavodsk Publ.

Lü, Q., Yan, J., Chen, X., Hou, H., Wan, W., \& Hu, Y. (2020). Progress of Deep Geological Survey Project under the China Geological Survey. China Geology, 3 (1), 153-172.

Orlov, V. P., \& Laverov, N. P. (1998). Scientific Results and research Experience. Moscow: MF Tekhnoneftegaz.

Sharov, N. V. (2012). Comparison of geophysical sections of the earth's crust with the results of drilling deep boreholes in the Fennoscandian shield. Geofizicheskiy zhurnal, 34 (4), 253-264.

Skuf'in, P. K. (2013). Basal volcanics of Pegenega complex (Lower Proterozoic, Kola Peninsula) on surface and in deep conditions (Kola Superdeep SG-3 Well). Bulletin Moskovskogo obshchestva ispytateley prirody, Otdel Geologichesky, 88 (6), 77-92.

Skuf'in, P. K., \& Lyutoyev, V. P. (2009). Composition and structural features of minerals of Early Proterozoic sedimentary rocks from the section of the Kola superdeep borehole and their homologs on the surface. Zapiski RMO, 138(3), 15-32.

Skuf'in, P. K., \& Vetrin, V. R. (2002). Kola Superdeep Borehole. In: F. P. Mitrofanov \& D. R. Zozulya (Eds.), Major Geological Sights of the Kola Peninsula. Apatity: Russian Academy of Sciences - Kola Science Center.

Skuf'in, P. K., Yakovlev, Y. N., \& Smirnov, Y. P. (1999). Geochemistry, structural features and ore content of rocks and minerals of the SG-3 Early Proterozoic section and their homologs from satellite wells and from the surface. In Rocks and minerals at great depths and on the earth's surface: subprojects. Apatity: Poligraf.

Yakovlev, Y. N., Yakovleva, A. K., \& Serov, P. A. (2017). New data on structure and composition of the Archaean complex in the SG-3 section. Vestnik Kolskogo nauchnogo tsentra, 3, 88-98.

Yakovlev, Y. N., Skuf'in, P. K., \& Chvykov, O. S. (2014.) Influence of natural factors on the trajectory and shape of the boreholes of the Kola Superdeep (SG-3). Vestnik Kolskogo nauchnogo tsentra, 3, 8-15.

Zhao, Y. S., Feng, Z. J., Xi, B. P., Yang, D., Liang, W. G., \& Wan, Z. J. (2017). Limit of crustal drilling depth. Journal of Rock Mechanics and Geotechnical Engineering, 9 (5), 989-992.

\section{SEMBLANCE OF THE AUTHORS}

Petr K. Skuf'in: He is a Full Doctor of Geological and Mineralogical Sciences, Professor, Leading Researcher at Geological Institute of the Kola Scientific Center of the Russian Academy of Science. His fields of scientific interests include geology, petrology, volcanology, petrography of igneous rocks, geochemistry 